\title{
An owl from the Paleocene of Walbeck, Germany
}

\author{
Gerald Mayr \\ With 3 figures and 1 table
}

\begin{abstract}
An owl of the genus Berruornis is described from a Paleocene fissure filling of Walbeck, Germany. The specimen is a well preserved incomplete right tarsometatarsus and is the earliest Old World record of an owl. A praemaxilla from the same locality which comes from a similarly-sized raptorial bird is described and is clearly distinguished from the praemaxilla of all extant raptorial birds. Although it might also belong to Berruornis, the specimen is classified as Aves incertae sedis in this study. Despite the fact that the Walbeck material was discovered more than 60 years ago, these two specimens are the first bird bones to be described from the numerous avian remains found at this locality.
\end{abstract}

Key words: Fossil birds, Paleocene, Walbeck, Strigiformes, Berruornis.

\section{Zusammenfassung}

Eine Eule der Gattung Berruornis wird aus einer paläozänen Spaltenfüllung von Walbeck, Deutschland, beschrieben. Das Exemplar ist ein gut erhaltenener, unvollständiger rechter Tarsometatarsus und ist der früheste altweltliche Nachweis einer Eule. Von der gleichen Lokalität wird eine Praemaxilla beschrieben, die von einem ähnlich großen Raubvogel stammt und sich deutlich von der Praemaxilla aller heutigen Raubvögel unterscheidet. Obwohl es auch zu Berruornis gehören könnte, wird das Stück als Aves incertae sedis klassifiziert. Ungeachtet der Tatsache, daß das Fossilmaterial von Walbeck bereits vor mehr als 60 Jahren entdeckt wurde, sind diese beiden Exemplare die ersten Knochen, die von den zahlreichen an dieser Lokalität gefundenen Vogelresten bisher beschrieben wurden.

Schlüsselwörter: Fossile Vögel, Paläozän, Walbeck, Strigiformes, Berruornis.

\section{Introduction}

Whereas there is an extensive record of Lower and Middle Eocene birds (e.g., Mlíkovský 1996, Mayr 2000), fossils of neornithine birds from earlier deposits are very scanty. Very few avian taxa are known from the Paleocene of Europe and virtually all of the described specimens come from the Reims area in north-eastern France (Mlikovský 1996). The taxa identified so far belong to large flightless birds of the families Remiornithidae and Gastornithidae, and to gruiform birds of the family Messelornithidae (Martin 1992, Mourer-Chauviré 1995, 1996). Most abundant among the small to mediumsized birds in the Paleocene of the Reims area is a species of owl (Strigiformes) which was described as Berruornis orbisantiqui by MourerChauviré (1994), and which was classified in the extinct family Sophiornithidae Mourer-Chauviré, 1987. The type series of Berruornis orbisantiqui consists of six isolated tarsometatarsi and a fragmentary distal end of a tibiotarsus from Mont Berru and the Cernay area. There were no other records of Berruornis. The tibiotarsus lacks an ossified pons supratendineus which is a synapomorphy of the Strigiformes.

In general, bird remains are rare in the French deposits (Russell 1964: 269). However, in 1939 a large number of avian bones were found in the Paleocene fissure fillings of Walbeck, Germany (Weigelt 1939). The Walbeck bird bones are among the earliest remains of neornithine birds known from Europe and are of great importance to our understanding of the early Tertiary avian diversification (see Weigelt 1939 and Russell 1964 for information on the geology of the site).

\footnotetext{
1 Forschungsinstitut Senckenberg, Sektion Ornithologie, Senckenberganlage 25, D-60325 Frankfurt am Main, Germany. E-mail: gmayr@sng.uni-frankfurt.de Received November 2001, accepted April 2002
} 
For several decades, part of the Walbeck avian fossils were on loan and only recently became available. Among these specimens is a tarsometatarsus of a large owl that belongs to the genus Berruornis and a very distinctive praemaxilla of a raptorial bird that has been mentioned by Weigelt (1939: 525). These bones are described herein, additional material unfortunately was not available for study.

\section{Material and method}

The osteological terminology used in this study follows Baumel \& Witmer (1993) and Baumel (1993). The specimens are deposited in the geological-palaeontological collections of the Institut für Geologische Wissenschaften und Geiseltalmuseum of Martin-Luther-Universität Halle-Wittenberg, Halle/ Saale, Germany (IGWuG).

\section{Systematic Paleontology}

Strigiformes Wagler, 1830

Sophiornithidae Mourer-Chauviré, 1987

Berruornis Mourer-Chauviré, 1994

\section{Berruornis sp.}

Fig. 1
Table 1

Dimensions of the tarsometatarsus of the Walbeck species of Berruornis and Berruornis orbisantiqui (after Mourer-Chauviré 1994) in comparison, in $\mathrm{mm}$.

\begin{tabular}{lll}
\hline Tarsometatarsus & $\begin{array}{l}\text { Berruornis } \\
\text { from Walbeck }\end{array}$ & $\begin{array}{l}\text { Berruornis } \\
\text { orbisantiqui } \\
\text { Mourer-Chauviré, } \\
1994\end{array}$ \\
\hline Total length & $\begin{array}{l}\sim 57 \\
(53.1 \text { as } \\
\text { preserved) }\end{array}$ & $68.5-74.0$ \\
& $\sim 15$ & $19.4-19.9$ \\
$\begin{array}{l}\text { Prox. width } \\
\text { Prox. depth }\end{array}$ & $\sim 9$ & $13.7-17.2$ \\
$\begin{array}{l}\text { Width shaft } \\
\text { in the middle }\end{array}$ & 10.8 & $11.8-16.2$ \\
$\begin{array}{l}\text { Depth shaft } \\
\text { in the Middle }\end{array}$ & 6.1 & $5.2-7.2$ \\
Distal width & $\sim 16-17$ & $23.7-24.1$
\end{tabular}

Referred specimen: WAL01.2001 (right tarsometatarsus missing parts of both articular ends), deposited in IGWuG.

Dimensions: See Table 1.

Description and comparison: The tarsometatarsus of the Walbeck species of Berruornis closely resembles that of $B$. orbisantiqui Mourer-Chauviré, 1994 in overall morphology. It is about the size of the corresponding bone of the extant Snowy Owl, Nyctea scandiaca, and is therefore from a large bird which was, however, smaller than $B$. orbisantiqui. A highly character-

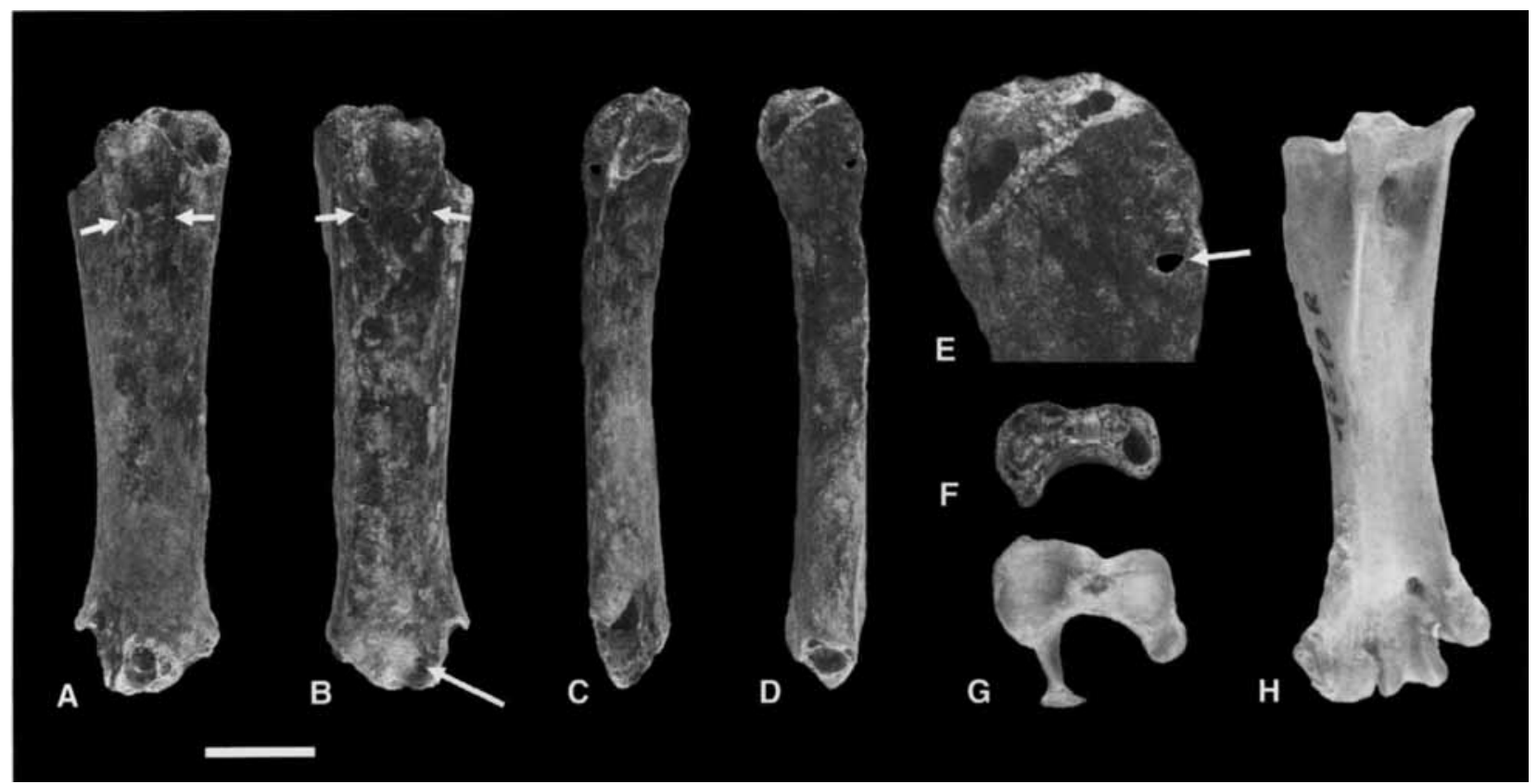

Fig. 1. Right tarsometatarsus of Berruornis sp. (Strigiformes, Sophiornithidae) (IGWuG WAL01.2001) (A-F) in comparison with the right tarsometatarsus of the extant Nyctea scandiaca (Strigidae) (G-H). A. Dorsal view; B. Plantar view; C. Lateral view; D. Medial view; E. Detail of medial side of proximal end; F. Proximal view; G. Proximal view; H. Plantar view. The small arrows point to the foramina vascularia proximalia, the medium-sized arrow indicates the foramen vasculare distale, and the large arrow points to the perforation in the crista medialis hypotarsi. The scale bar equals $10 \mathrm{~mm}$. 
istic derived and diagnostic feature of the genus Berruornis, which is also seen in the specimen from Walbeck, is the presence of a perforation in the crista medialis hypotarsi (Fig. 1E), through which probably one of the arteriae metatarsales plantares passed (Mourer-Chauviré 1994). Although the bone lacks most of the proximal end, a small part of the articulation surface of the cotyla medialis is preserved which allows an estimate to be made of the original length of the tarsometatarsus (Tab. 1). It is clearly visible that the metatarsals are completely fused, which indicates that the specimen is from an adult bird.

As in Berruornis orbisantiqui, but contrary to most other owls, the fossa infracotylaris dorsalis is shallow. The crista medialis hypotarsi is broken. The foramina vascularia proximalia are larger than in $B$. orbisantiqui, but as in the latter species the lateral foramen vasculare proximale is situated slightly more proximal than the medial foramen. The shaft of the bone is most narrow at the approximate level of the fossa metatarsi I and becomes gradually wider towards its proximal end, whereas the shaft of the tarsometatarsus of Berruornis orbisantiqui has a nearly equal width over its length. It is narrow in dorso-plantar direction and slightly curved if viewed from its lateral side. The proximal part of the plantar surface of the shaft is distinctly concave, but becomes flat towards the distal end. The dorsal surface of the distal end is slightly convex. The fossa metatarsi $\mathrm{I}$ is very indistinct, but ap- pears to have been situated on the medial surface of the shaft. As in B. orbisantiqui, the foramen vasculare distale is very small, but contrary to the latter species it is situated far distally, on the bottom of a sulcus between the trochleae metatarsorum III and IV (Fig. 1). All trochleae metatarsorum are broken, but what remains indicates that the trochlea metatarsi III was narrow as in $B$. orbisantiqui, and that the trochlea metatarsi IV was situated farther proximally than the other trochleae.

\section{Aves incertae sedis}

Fig. 2

Referred specimen: WAL02.2001 (praemaxilla lacking the tip), deposited in IGWuG.

Locality and horizon: Walbeck near Helmstedt, Germany; Upper Paleocene, ?MP 5 (BiochroM'97 1997).

Dimensions: Maximum length as preserved (from tip of processus frontalis to broken tip of the rostral end), 31.1; medio-lateral width at caudal end of praemaxillary symphysis, 8.1 ; dorsoventral depth at caudal end of praemaxillary symphysis, 12.9 .

Description and comparison: The praemaxilla is from a large raptorial bird about the size of the extant King Vulture, Sarcoramphus papa (New World vultures, Cathartidae), but dif-

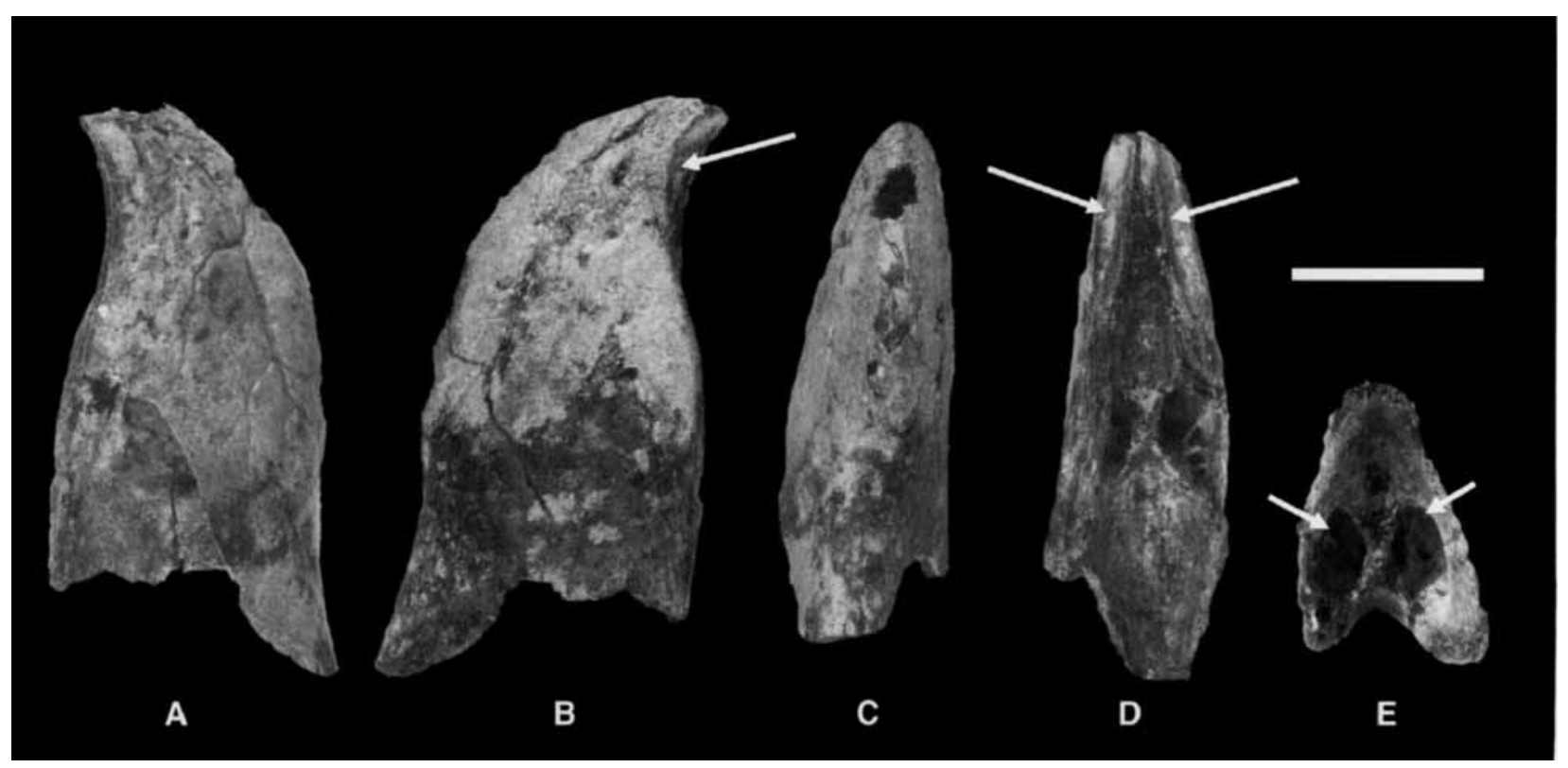

Fig. 2. Aves incertae sedis, praemaxilla (IGWuG WAL02.2001). A. Left lateral view; B. Right lateral view; C. Dorsal view; D. Ventral view; E. Caudal view. The large arrows indicate the sulci along the lateral sides of the praemaxillary symphysis, the small arrows point to the large oval openings inside the tip of the rostrum. The scale bar equals $10 \mathrm{~mm}$. 
fers from the praemaxillae of all extant raptorial birds in its morphology.

Most unusual is its medio-lateral narrowness in which it resembles the praemaxillae of the extant Egyptian Vulture, Neophron percnopterus, and Hooded Vulture, Necrosyrtes monachus, and also that of the Phorusrhacidae (extinct, flightless and raptorial, gruiform birds, e.g., Sinclair \& Farr 1932). The lateral sides are steeply sloping and bear many distinct impressions of blood vessels and a row of distinct foramina neurovascularia. As in extant cathartid vultures (e.g., Cathartes aura, Fig. 3), the cristae tomiales are sigmoidally curved. Also as in New World vultures, but contrary to all other extant raptors, the culmen (i.e. the dorsal margin of the beak) is angled at the rostral end of the processus frontalis of the os praemaxillare, whereas in owls, falcons, and hawks, the culmen is uniformly convex. The tip of the specimen is broken but what remains leaves no doubt that it was pointed.

The preserved part of the processus frontalis of the os praemaxillare has a strongly arched cross section. Contrary to extant Strigiformes and all diurnal raptors except the Cathartidae, the Walbeck beak apparently lacked an ossified internarial septum. The rostral margin of the narial openings is not preserved.

In ventral view, the Walbeck praemaxilla differs from that of extant Falconidae (falcons and allies) and Accipitridae (hawks and allies) but agrees with Strigiformes and Cathartidae in that the ossa maxillaria are separated by a wide gap.

The ventral surface of the rostral end of the praemaxillary symphysis is very distinctive because it has two sulci along its lateral sides, each of $9 \mathrm{~mm}$ length. Similar sulci are only found in extant falcons (Falconidae) and, much less pronounced, in cathartid vultures (Figs 2, 3). These sulci are especially distinct in the Common Caracara, Polyborus plancus (Falconidae, Fig. 3), but in contrast to this species and other Falconidae they are not separated by a medial ridge in the Walbeck specimen but by a narrow furrow. In the area of these sulci the cristae tomiales are reduced, more caudad their cutting edge is blunt and fairly wide medio-laterally. Caudad to these sulci, the ventral surface of the praemaxillary symphysis is concave.

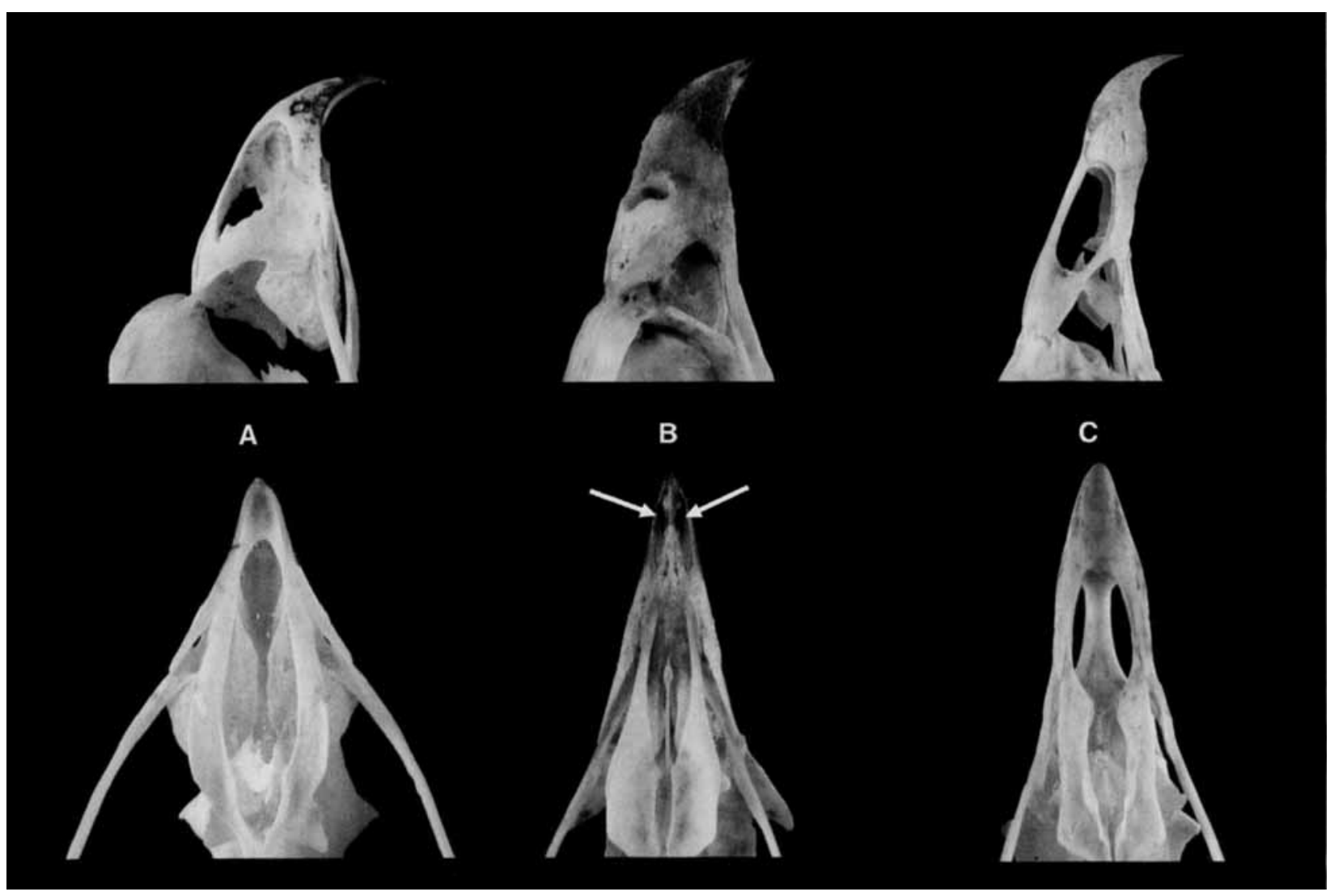

Fig. 3. Praemaxillae of extant raptorial birds in comparison (upper row: right lateral view, lower row: ventral view). A. Nyctea scandiaca (Strigidae, Strigiformes). B. Polyborus plancus (Falconidae, Falconiformes). C. Cathartes aura (Cathartidae, ?Ciconiiformes). The arrows indicate the sulci along the lateral sides of the praemaxillary symphysis in Polyborus plancus. 
In caudal view, two large oval openings, which are separated by a narrow osseous medial bar can be seen inside the tip of the rostrum, at the caudal end of the praemaxillary symphysis (Fig. 2E). This structure might be plesiomorphic within neognathous birds, but among extant raptors I found these openings only within the praemaxilla of the Strigiformes and - to a varying degree - in the Cathartidae (the openings are well developed in Cathartes aura, but very small in Coragyps atratus).

\section{Discussion}

The Walbeck species of Berruornis is the first record of Berruornis outside France. Since the fissure fillings of Walbeck are older than the deposits of the Reims area in France (which are from the stratigraphic level MP 6; see BiochroM'97 1997: Tab. 3), the Walbeck species is the earliest record of an owl from Europe. Although the above described tarsometatarsus probably belongs to a new species of Berruornis, it has not been named because of its incomplete preservation.

Owls have an extensive fossil record and are already diverse by the early Tertiary (see Mourer-Chauviré 1987, 1994 and references therein). Apart from Berruornis only a single other Paleocene strigiform taxon is known. This bird, which was assigned to the genus Ogygoptynx within a monotypic family Ogygoptyngidae, is based on a tarsometatarsus from the Middle Paleocene (Tiffanian) of Colorado, North America (Rich \& Bohaska 1976, 1981), which differs distinctly from the corresponding bone of Berruornis (see Mourer-Chauviré 1994).

Mourer-Chauviré (1994) assigned Berruornis to the extinct family Sophiornithidae that also includes Sophiornis Mourer-Chauviré, 1987 from the Middle Eocene to Upper Oligocene of the Quercy, France. I adopted this classification in the present study, however it should be noted that the similarities between Berruornis and Sophiornis in which these taxa differ from other owls are probably plesiomorphic within the Strigiformes, e.g. the shallow fossa infracotylaris dorsalis and the trochleae metatarsorum being arranged on a weakly curved line. The latter two features were listed by Mourer-Chauviré (1987: $125)$ to support a sister group relationship between the Sophiornithidae and all other owls that exhibit the derived condition of these characters (i.e. a deeply excavated fossa infracotylaris dorsalis and trochleae metatarsorum II and IV which are strongly turned plantarly).

Its fragmentary nature and our poor knowledge on Paleocene avifaunas do not allow a definitive assignment of the Walbeck praemaxilla. However, the specimen corresponds well in size to the tarsometatarsus of the Walbeck species of Berruornis, and might belong to this species. It differs from the praemaxilla of extant owls in the absence of an ossified internarial septum, in the angled culmen, and in the presence of distinct sulci along the ventral surface of the rostral end of the praemaxillary symphysis. Beaks of early Tertiary owls are unknown so far, and the differences between the Paleocene praemaxilla and that of extant Strigiformes might well be plesiomorphic within owls (absence of an ossified internarial septum) or autapomorphic for Berruornis (sulci along praemaxillary symphysis). Because the trochleae metatarsorum are arranged on a weakly curved line, Mourer-Chauviré (1994: 347) concluded that Berruornis either was more terrestrial than extant owls or that its grasping abilities were less developed. In both cases it is possible that Berruornis also had a different feeding technique than extant owls and thus a different bill morphology.

A raptorial beak is also characteristic for the Phorusrhacidae of which some putative members were described from the early Tertiary of Europe (Mourer-Chauviré 1981, Peters 1987). The skull of the European taxa is unknown, but in the known skulls of the South American Phorusrhacidae the ventral surface of the beak is also more heavily ossified than in the Walbeck praemaxilla (see Sinclair \& Farr 1932). Given the fact, however, that there is no convincing evidence for an assignment of the Walbeck praemaxilla to Berruornis, it has been assigned to Aves incertae sedis.

Dating back at least 58 million years (to BiochroM'97 1997, Legendre and Lévêque 1997), the fissure fillings of Walbeck were deposited less than 7 million years after the CretaceousTertiary mass extinction event. The fact that the Walbeck avifauna is already very diversified (see the numerous bones of different avian taxa figured by Weigelt 1939: pl. 7) rather supports a Cretaceous origin of many neornithine higher taxa (Cooper \& Penny 1997, Cracraft 2001), than their explosive radiation in the early Tertiary (Feduccia 1995). 


\section{Acknowledgements}

I thank R. Böttcher (Staatliches Museum für Naturkunde, Stuttgart) and N. Hauschke (IGWuG) for the loan of the fossil specimens, and S. Tränkner (Forschungsinstitut Senckenberg) for taking the photographs. I also thank B. Chandler (Milledville), P. Ericson (Stockholm) and D. Unwin (Berlin) for reviewing the manuscript.

\section{References}

Ballmann, P. 1969. Die Vögel aus der altburdigalen Spaltenfüllung von Wintershof (West) bei Eichstätt in Bayern. Zitteliana 1: 5-60.

Baumel, J. J. 1993. Systema cardiovasculare. In Baumel, J. J., King, A. S., Breazile, J. E., Evans, H. E. \& Vanden Berge, J. C. (eds). Handbook of Avian Anatomy: Nomina Anatomica Avium. - Publications of the Nuttall Ornithological Club 23: 407-475.

Baumel, J. J. \& Witmer, L. M. 1993. Osteologia. In Baumel, J. J., King, A. S., Breazile, J. E., Evans, H. E. \& Vanden Berge, J. C. (eds). Handbook of Avian Anatomy: Nomina Anatomica Avium. - Publications of the Nuttall Ornithological Club 23: 45-132.

BiochroM'97. 1997. Synthèses et tableaux de corrélations/ Syntheses and correlation tables. In Aguilar, J.-P., Legendre, S. \& Michaux, J. (eds), Actes du Congrès BiochroM'97. - Mémoires et Travaux de l'Ecole Pratique des Hautes Etudes, Institut de Montpellier 21: 769-805.

Cooper, A. \& Penny, D. 1997. Mass survival of birds across the Cretaceous-Tertiary boundary: molecular evidence. Science 275: 1109-1113.

Cracraft, J. 2001. Avian evolution, Gondwana biogeography and the Cretaceous-Tertiary mass extinction event. - Proceedings of the Royal Society of London (B) 268: 459-469.

Feduccia, A. 1995. Explosive evolution in Tertiary birds and mammals. - Science 267: 637-638.

Legendre, S. \& Lévêque, F. 1997. Etalonnage de l'échelle biochronologique mammalienne du Paléogène d'Europe occidentale: vers une intégration à l'échelle globale. In Aguilar, J.-P., Legendre, S. \& Michaux, J. (eds). Actes du Congrès BiochroM'97. - Mémoires et Travaux de l'Ecole Pratique des Hautes Etudes, Institut de Montpellier 21: $461-473$.
Martin, L. D. 1992. The Status of the Late Paleocene Birds Gastornis and Remiornis. In Campbell, K. E. (ed.). Papers in Avian Paleontology honoring Pierce Brodkorb. Natural History Museum of Los Angeles County, Science Series 36: 97-108.

Mayr, G. 2000. Die Vögel der Grube Messel - ein Einblick in die Vogelwelt Mitteleuropas vor 49 Millionen Jahren. - Natur und Museum 130: 365-378.

Mlíkovský, J. 1996. Tertiary Avian Faunas of Europe; pp. In Mlikovský, J. (ed.). Tertiary Avian Localities of Europe. - Acta Universitatis Carolinae, Geologica 39: 777-818.

Mourer-Chauviré, C. 1981. Première indication de la présence de Phorusrhacidés, famille d'oiseaux géants d'Amérique du Sud, dans le Tertiaire européen: Ameghinornis nov. gen. (Aves, Ralliformes) des Phosphorites du Quercy, France. - Géobios 14 (5): 637-647.

- 1987. Les Strigiformes (Aves) des phosphorites du Quercy (France): Systematique, biostratigraphie et paleobiogeographie. - Documents des Laboratoires de Géologie de Lyon 99: 89-135.

- 1994. A large owl from the Palaeocene of France. - Palaeontology 37: 339-348.

- 1995. The Messelornithidae (Aves: Gruiformes) from the Paleogene of France. - Courier Forschungsinstitut Senckenberg 181: 95-105.

- 1996. Paleogene Avian Localities of France. - Acta Universitatis Carolinae Geologica 39: 567-598.

Peters, D. S. 1987. Ein "Phorusrhacide" aus dem Mittel-Eozän von Messel (Aves: Gruiformes: Cariamae). - Documents des Laboratoires de Géologie de Lyon 99: 71-87.

Rich, P. V. \& Bohaska, D. J. 1976. The World's Oldest Owl: A New Strigiform from the Paleocene of Southwestern Colorado. - Smithsonian Contributions to Paleobiology 27: 87-93.

- 1981. The Ogygoptyngidae, a new family of owls from the Paleocene of North America. - Alcheringa 5: 95-102.

Russell, D. E. 1964. Les mammifères paléocènes d'Europe. Mémoires du Muséum national d'Histoire naturelle de Paris, série C 13: 1-324.

Sinclair, W. J. \& Farr, M. S. 1932. Aves of the Santa Cruz Beds. - Reports of the Princetown University Expeditions to Patagonia 7, part 2: 157-191.

Weigelt, J. 1939. Dic Aufdeckung der bisher ältesten tertiären Säugetierfauna Deutschlands. - Nova Acta Leopoldina, N.S. 7: $515-528$. 